\title{
Lethal Effects of Toxic Plants (Neem, Datura, Acanthus) on Artemia Species
}

\author{
T. A. Jihad, M. S. Bhuyan*, M. S. Islam \\ Institute of Marine Sciences and Fisheries, University of Chittagong, Chittagong, Bangladesh
}

Received 17 April 2018, accepted in final revised form 14 October 2018

\begin{abstract}
Effects of the water-soluble extracts (dry leaf powder of Azadirachta indica, Datura stramonium and Acanthus ilicifolius) were studied on the behavioral pattern and mortality of Artemia species. The extracts of all the plants brought significant change in the behavioral pattern of Artemia. The Artemia become agitated just offer exposure to the extract and started to move upwards and downwards vigorously. The Artemia exposed to the various concentration of water-soluble plant extracts were unable to maintain dorsoventral position and dropped to the bottom finally. The mortality rates recorded after $24 \mathrm{~h}$ exposure to the extract Azadirachta indica were $30 \%$ at $1500 \mathrm{mg} / \mathrm{L}$ and $70 \%$ at $3000 \mathrm{mg} / \mathrm{L}$. Similarly, after $24 \mathrm{~h}$ exposure to the extracts of Datura stremonium, the mortality rates were $40 \%$ at $2000 \mathrm{mg} / \mathrm{L}$ and $75 \%$ at $3500 \mathrm{mg} / \mathrm{L}$. Again, after $24 \mathrm{~h}$ has exposure to the extracts of Acanthus ilicifolius, the mortality rates were $35 \%$ at $2500 \mathrm{mg} / \mathrm{L}$ and rose to $80 \%$ at $4000 \mathrm{mg} / \mathrm{L}$. The $24 \mathrm{~h} \mathrm{LC}_{50}$ values of the water-soluble extracts of Neem, Datura and Acanthus were 2331.930, 2357.948 and 2922.957. Artemia was more sensitive to the watersoluble extract of Neem than Datura and Acanthus.
\end{abstract}

Keywords: Lethal effects; Toxic plants; Mortality; Behavioral pattern; Artemia.

๑) 2019 JSR Publications. ISSN: 2070-0237 (Print); 2070-0245 (Online). All rights reserved. doi: http://dx.doi.org/10.3329/jsr.v11i1.36424 J. Sci. Res. 11 (1), $83-88$ (2019)

\section{Introduction}

Artemia is one kind of zooplankton popularly known as brine shrimp [1]. It is widely distributed on the five continents in hyper saline biotopes including salt lakes coastal or inland waters rich in chloride, sulphate or carbonate and especially in coastal salinas [2]. It is about $12 \mathrm{~mm}$ in length. Artemia is a high saline organism (20-300 ppt) [3,4]. They can survive short periods of time in the fresh water but cannot reproduce. The optimum temperature is 20 to $55^{\circ} \mathrm{C}$ for Artemia to survive. They have two modes of reproduction [5]. Artemia life cycle begins by the hatching of dormant cysts, which are encased embryos that are metabolically inactive. The cysts can remain dormant for many years as long as they are kept in dry and oxygen-free condition [6]. Surgeloss [7] reported that Artemia has a very efficient ecological defense mechanism. It has great practical value

\footnotetext{
*Corresponding author: simulbhuyan@gmail.com
} 
because of its availability as day cysts. However, since the demand perennially treats, it is always in short supply and thus very expensive.

Artemia used as feed in the hatchery and they can be used as feed mixed with artificial diets as a source of protein as an attractant [8]. Artemia is an excellent food for newly hatched fish [9] and shrimp larvae [10]. The nauplii of Artemia are readily taken by aquatic animals in nursery stage.

There are many kinds of toxic plants in the natural environment [11]. These toxic plants have a great impact on the brine shrimp Artemia [12]. Toxicity of plants to planktonic fauna (Artemia salina) is different from plants to plants [13]. In the present experiment Azadirachta indica (Neem), Datura stremonium (Datura) and Acanthus ilicifolius (Acanthus) are used as toxic plants to assess the extent of toxicity of these plants on Artemia.

\section{Materials and Methods}

The experiment was conducted in the laboratory of the Institute of Marine Sciences and Fisheries, the University of Chittagong from May to August 2016. The fresh leaves of Neem, Datura, and Acanthus were collected from the south campus of the area of Chittagong University and Coastal area of Cox's Bazar. The collected leaves of the plants were dried at room temperature and then heated in an oven at $(50-60)^{\circ} \mathrm{C}$ until a constant weight of the samples were reached. The dried samples were powdered with the help of a powder driven grinder.

Three water-soluble extracts were prepared from the dried powdered leaves of Neem, Datura, and Acanthus. For the preparation of a stock solution, the dried powders were mixed thoroughly with distilled water at a ratio 1:10, that means one gram powder was mixed with $10 \mathrm{~mL}$ of distilled water. The mixture was left at room temperature for $24 \mathrm{~h}$. The mixture was then filtered with fine mesh clothing. Thus a crude extract was obtained. It was collected in a conical flask and stored in a refrigerator at $4{ }^{\circ} \mathrm{C}$ as a stock solution.

\subsection{Saline water preparation}

Concentrated brine was collected from the salt bed of Chakaria coast, Cox's Bazar. The brine was mixed with tap water. $1 \mathrm{~kg}$ of mud was mixed with ten liters of the tap water in an aquarium for the better adaptation. Gradually, $5 \mathrm{~kg}$ mud was mixed with $50 \mathrm{~L}$ of the tap water.

\subsection{Experimental setting}

Three aquaria of equal size $\left(30^{\prime \prime} \times 18^{\prime \prime} \times 16^{\prime \prime}\right)$ washed with tap water were set up in a ventilated and damp proof room. Necessary equipment and chemicals were collected and set in a laboratory for measuring the water parameters of the aquaria. Each saline water provided with a mechanical aerator. Experimental setup for the toxicity test with different plants is shown in Fig. 1. 


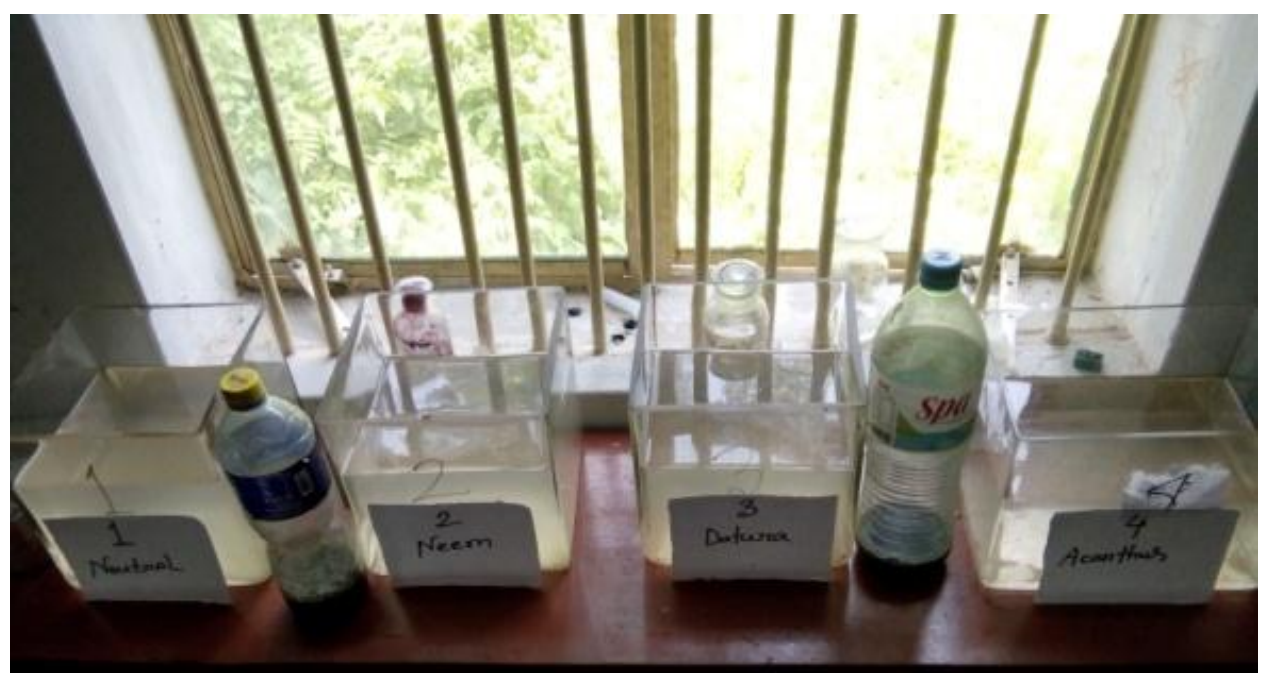

Fig. 1. Experimental setting.

\subsection{Artemia collection and acclimatization}

Artemia was collected from local market of Cox's Bazar [14]. After collection, Artemia was put in a plastic bowl. Then a jar was taken and three liters of saline water (20 ppt) was put in the jar. Then Artemia cysts were poured in the jar. Then an aerator was linked in the jar for aeration and waited 2 days for hatching. After hatching, the cysts of Artemia was poured in the aquarium containing saline water $(20 \mathrm{ppt})$. Gradually after hatching, Artemia started to grow large [15]. Then egg sperm was given as a feed for newly hatched Artemia. Salinity, temperature, $\mathrm{pH}$ were measured with the help of refractometer, thermometer and pH meter. Then waited for three weeks until the Artemia gained matured size. After gaining matured size, the toxicity test was executed.

\subsection{Observation of physico-chemical variables}

Salinity, temperature and $\mathrm{pH}$ of the aquaria water were measured with the help of refractometer (Model: DR103, The United Kingdom), thermometers, and Hanna pH meter (HI 9124 HI 9125, China) respectively. Dissolved oxygen is determined by the titrimetric method developed by Winkler [16].

\subsubsection{Calculation}

Dissolved oxygen $\mathrm{ppm}=$ volume of sodium thiosulphate consumed in $\mathrm{mL} \times$ its normality $\times 0.008 \times 10^{6}$ /volume of sample in $\mathrm{mL}$. 


\subsection{Toxicity test}

For the toxicity test, four jars were taken with four liters saline water. Then 20 species of Artemia was given into each jar. After that, different concentration (e.g. 1500, 2000, 2500, $3000,3500 \mathrm{mg} / \mathrm{L}$ ) of leaf powder was given to the Artemia species in each jar with micro pipette. Then reading was taken after $6,12,18$ and $24 \mathrm{~h}$. After that, the mortality rate was calculated. The measured water parameter of the aquarium was (salinity 20-70) ppt, temperature $(28-30)^{\circ} \mathrm{C}, \mathrm{pH}(6.8 \pm 0.13)$ and dissolved oxygen $(8.5 \pm 0.20) \mathrm{mg} / \mathrm{L}$. The experiment was repeated twice for the three plants extracts.

\subsection{Statistical analysis}

All the data were analyzed statistically. Statistical analyses were done by Probit analysis [17]. Probit analysis suggested by Fisher and Yates [18] was followed graphically and for determining the $\mathrm{LC}_{50}$ values mathematically. The values for empirical Probit, working Probit were taken from the tables given by Finney [19].

\section{Results and Discussion}

From the present study it was found that the water-soluble extracts of the leaf powder of the indigenous plant's species (Neem, Datura and Acanthus) were effective in killing the Artemia at low concentration $1500 \mathrm{mg} / \mathrm{L}$ in Neem, $2000 \mathrm{mg} / \mathrm{L}$ in Datura and $2500 \mathrm{mg} / \mathrm{L}$ in Acanthus. Behavioral changes become gradually apparent with the increase in the exposures of time and concentration. At medium concentrations $2000 \mathrm{mg} / \mathrm{L}$ to $2500 \mathrm{mg} / \mathrm{L}$ in Neem and $2500 \mathrm{mg} / \mathrm{L}$ to $3000 \mathrm{mg} / \mathrm{L}$ Datura and $3000 \mathrm{mg} / \mathrm{L}$ to $3500 \mathrm{mg} / \mathrm{L}$ in Acanthus, Artemia subjected to change in their behavioral pattern. The Artemia began to move up and down vigorously soon after they were released into the higher concentration and came up to the surface repeatedly. After a considerable period of time, the Artemia lost their stability to swim. Their movement becomes slow down and closed their mouths, consequently, the whole body becomes paralyzed. Finally, mortality occurred at a different interval of time.

Different concentrations of the water extracts caused varying rates of Artemia mortality during the $24 \mathrm{~h}$ exposure period. In all cases, the mortality rate was low at low concentration and it increased with the increased concentration and exposure time. The mortality recorded after $24 \mathrm{~h}$ exposures to the extracts of Azadirachta indica were $30 \%$ at $1500 \mathrm{mg} / \mathrm{L}$ and increased to $70 \%$ at $3000 \mathrm{mg} / \mathrm{L}$ (Table 1). 
Table 1. Mortality of Artemia exposed to the water-soluble extracts of Azadirachta indica.

\begin{tabular}{|c|c|c|c|c|c|c|c|c|c|c|}
\hline \multirow{3}{*}{$\begin{array}{l}\text { Name of } \\
\text { the plant } \\
\text { extract }\end{array}$} & \multirow{3}{*}{$\begin{array}{l}\text { Artemia } \\
\text { (Species) }\end{array}$} & \multirow{3}{*}{$\begin{array}{l}\text { Concentration } \\
(\mathrm{mg} / \mathrm{L})\end{array}$} & \multicolumn{8}{|c|}{ Number of Artemia species died after exposure (h) } \\
\hline & & & \multicolumn{2}{|l|}{6} & \multicolumn{2}{|l|}{12} & \multicolumn{2}{|l|}{18} & \multicolumn{2}{|l|}{24} \\
\hline & & & $\begin{array}{l}\text { No. } \\
\text { of } \\
\text { died }\end{array}$ & $\begin{array}{l}\mathrm{M} \\
\%\end{array}$ & $\begin{array}{l}\text { No. } \\
\text { of } \\
\text { died }\end{array}$ & $\begin{array}{l}\mathrm{M} \\
\%\end{array}$ & $\begin{array}{l}\text { No. } \\
\text { of } \\
\text { died }\end{array}$ & $\begin{array}{l}\mathrm{M} \\
\%\end{array}$ & $\begin{array}{l}\text { No. } \\
\text { of } \\
\text { died }\end{array}$ & $\begin{array}{l}\mathrm{M} \\
\%\end{array}$ \\
\hline \multirow{5}{*}{ 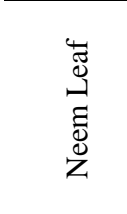 } & 20 & Control & 0 & 0 & 0 & 0 & 0 & 0 & 0 & 0 \\
\hline & 20 & 1500 & 0 & 0 & 1 & $5 \%$ & 3 & $15 \%$ & 6 & $30 \%$ \\
\hline & 20 & 2000 & 0 & 0 & 2 & $10 \%$ & 4 & $20 \%$ & 7 & $35 \%$ \\
\hline & 20 & 2500 & 1 & $5 \%$ & 3 & $15 \%$ & 6 & $30 \%$ & 10 & $50 \%$ \\
\hline & 20 & 3000 & 2 & $10 \%$ & 5 & $25 \%$ & 9 & $45 \%$ & 14 & $70 \%$ \\
\hline
\end{tabular}

After $24 \mathrm{~h}$ exposure to the extracts of Datura stremonium mortality was $40 \%$ at 2000 $\mathrm{mg} / \mathrm{L}$ and raised to $75 \%$ at $3500 \mathrm{mg} / \mathrm{L}$ (Table 2).

Table 2. Mortality of Artemia exposed to the water-soluble extracts of Datura stremonium.

\begin{tabular}{|c|c|c|c|c|c|c|c|c|c|c|}
\hline \multirow{3}{*}{$\begin{array}{l}\text { Name of } \\
\text { the plant } \\
\text { extract }\end{array}$} & \multirow{3}{*}{$\begin{array}{l}\text { Artemia } \\
\text { (Species) }\end{array}$} & \multirow{3}{*}{$\begin{array}{l}\text { Concentration } \\
(\mathrm{mg} / \mathrm{L})\end{array}$} & \multicolumn{8}{|c|}{ Number of Artemia species died after exposure (h) } \\
\hline & & & 6 & & 12 & & 18 & & 24 & \\
\hline & & & $\begin{array}{l}\text { No. of } \\
\text { mortality }\end{array}$ & $\begin{array}{l}\mathrm{M} \\
\%\end{array}$ & $\begin{array}{l}\text { No. of } \\
\text { mortality }\end{array}$ & $\begin{array}{l}\mathrm{M} \\
\%\end{array}$ & $\begin{array}{l}\text { No. of } \\
\text { mortality }\end{array}$ & $\begin{array}{l}\mathrm{M} \\
\%\end{array}$ & $\begin{array}{l}\text { No. of } \\
\text { mortality }\end{array}$ & $\begin{array}{l}\mathrm{M} \\
\%\end{array}$ \\
\hline \multirow{5}{*}{ 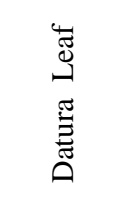 } & 20 & Control & 0 & 0 & 0 & 0 & 0 & 0 & 0 & 0 \\
\hline & 20 & 2000 & 0 & 0 & 2 & $10 \%$ & 5 & $25 \%$ & 8 & $40 \%$ \\
\hline & 20 & 2500 & 1 & $5 \%$ & 3 & $15 \%$ & 6 & $30 \%$ & 10 & $50 \%$ \\
\hline & 20 & 3000 & 2 & $10 \%$ & 5 & $25 \%$ & 9 & $45 \%$ & 14 & $70 \%$ \\
\hline & 20 & 3500 & 2 & $10 \%$ & 5 & $25 \%$ & 10 & $50 \%$ & 15 & $75 \%$ \\
\hline
\end{tabular}

After $24 \mathrm{~h}$ exposure to the extracts of Acanthus ilicifolius mortality was $35 \%$ at 2500 $\mathrm{mg} / \mathrm{L}$ and raised to $80 \%$ at $4000 \mathrm{mg} / \mathrm{L}$. The $24 \mathrm{~h} \mathrm{LC} \mathrm{LC}_{50}$ values for the different concentrations of the extract of Azadirachta indica, Datura stremonium and Acanthus ilicifolius are given in Table 3.

Table 3. Mortality of Artemia exposed to the water-soluble extracts of Acanthus ilicifolius.

\begin{tabular}{|c|c|c|c|c|c|c|c|c|c|c|}
\hline \multirow{3}{*}{$\begin{array}{l}\text { Name of } \\
\text { the plant } \\
\text { extract }\end{array}$} & \multirow{3}{*}{$\begin{array}{l}\text { Artemia } \\
\text { (Species) }\end{array}$} & \multirow{3}{*}{$\begin{array}{l}\text { Conc. } \\
(\mathrm{mg} / \mathrm{L})\end{array}$} & \multicolumn{8}{|c|}{ Number of Artemia species died after exposure (h) } \\
\hline & & & \multicolumn{2}{|l|}{6} & \multicolumn{2}{|l|}{12} & \multicolumn{2}{|l|}{18} & \multicolumn{2}{|l|}{24} \\
\hline & & & $\begin{array}{l}\text { No. of } \\
\text { mortality }\end{array}$ & $\begin{array}{l}\mathrm{M} \\
\%\end{array}$ & $\begin{array}{l}\text { No. of } \\
\text { mortality }\end{array}$ & $\begin{array}{l}\mathrm{M} \\
\%\end{array}$ & $\begin{array}{l}\text { No. of } \\
\text { mortality }\end{array}$ & $\begin{array}{l}\mathrm{M} \\
\%\end{array}$ & $\begin{array}{l}\text { No. of } \\
\text { mortality }\end{array}$ & $\begin{array}{l}\mathrm{M} \\
\%\end{array}$ \\
\hline \multirow{5}{*}{ 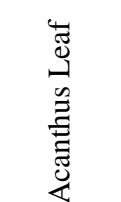 } & 20 & Control & 0 & 0 & 0 & 0 & 0 & 0 & 0 & 0 \\
\hline & 20 & 2500 & 0 & 0 & 1 & $5 \%$ & 3 & $15 \%$ & 7 & $35 \%$ \\
\hline & 20 & 3000 & 1 & $5 \%$ & 3 & $15 \%$ & 6 & $30 \%$ & 10 & $50 \%$ \\
\hline & 20 & 3500 & 2 & $10 \%$ & 5 & $25 \%$ & 9 & $45 \%$ & 14 & $70 \%$ \\
\hline & 20 & 4000 & 3 & $15 \%$ & 6 & $30 \%$ & 10 & $50 \%$ & 16 & $80 \%$ \\
\hline
\end{tabular}




\section{Conclusion}

Toxic plants have a great impact to brine shrimp Artemia species. After giving the concentration of leaf powder, Artemia species gradually lose their surviving attitude. Then mortality rates recorded after $24 \mathrm{~h}$ exposure. Lethal effects of toxic plants on Artemia is an exceptional task and it will bring new dimensions for the researcher in the future.

\section{References}

1. M. H. Al-Seria, R. R. Al-Ani, and A. G. Anwer, Baghdad Sci. J. 8, 66 (2011).

2. W. Tackaert and P. Sorgeloos, The Use of Brine Shrimp Artemia in Biological Management of Solar Salt Works (1993) pp. 617.

3. G. Van Stappen, G. Fayazi, and P. Sorgeloos. Hydrobiologia 466, 133 (2001). https://doi.org/10.1023/A:1014510730467

4. W. D. Williams, Environ. Conservation 29, 154 (2002). https://doi.org/10.1017/S0376892902000103

5. G. D. Treece, Artemia Production for Marine Larval Fish Culture, Southern Sorgeloos, ed. D. A. Bengtson et al. (Artemia Research and its Wettern, Belgium, 2000) p. 201.

6. G. V. V. Stappen, Introduction, Biology and Ecology of Artemia (Laboratory of Aquaculture and Artemia Ref. cent. University of Gent, Belgium, 1996).

7. P. Sorgeloos, The Use of Brine Shrimp Artemia in Aquaculture, the Brine shrimp Artemia. Ecology, Culturing, Use in Aquaculture, ed. G. Persoone et al. (Universa Press, Wetteren, Belgium, 1980) 3, pp. 25.

8. P. Leger, D. A. Bengtson, P. Sorgeloos, K. L. Simpson, and A. D. Beck, The Nutritional Value of Artemia: A Review In: Artemia Research and its Applications. Ecology, Culturing, Use in Aquaculture, ed. P. Sorgeloos et al. (Universa Press, Wetteren, Belgium 556, 1987) 3, pp. 357.

9. A. Seale, Trans. American Fisher. Soci. 63, 129 (1933).

10. M. Hudinaga, National Res. Coun. Japan 10, 305 (1942).

11. A. Ghani, Asiat. Soc. Bangladesh (2003).

12. A. Aktar, M. Sc Thesis, University of Dhaka, Bangladesh (1996).

13. T. W. Sam, Toxicity Testing Using the Vrine Shrimp: Artemia salina. In Bioactive Natural Products Detection, Isolation and Structural Determination, ed. S. M. Colegate et al. (CRC press, Baca Raton, FL, 1993) pp. 442.

14. M. R. Chowdhury, M.Sc. thesis, IMSF, Chittagong University, Bangladesh (1986).

15. I. A. Chowdhury, Study on Artemia Biomass Production in Outdoor Culture at a Hatchery in Cox's Bazar (IMSF. Chittagong University, Bangladesh, 2005).

16. L. W. Winkler, The Determination of Dissolved Oxygen in Water, Berlin. Deut. Chem. yeas, 21.2845 Nov, 133 (1981).

17. D. J. Finney, Probit Analysis, $3^{\text {rd }}$ Edition (Cambridge University Press, London, 1971) pp. 333.

18. R. A. Fisher and F. Yates, Statistical Tables for Biological, Agricultural and Medicinal Research, $6^{\text {th }}$ Edition (Oliver and Boyd Ltd., Edinburgh, 1963) pp. 34.

19. D. J. Finney, Probit Analysis (Cambridge University Press, London, 1949) pp.137. 